\title{
A cognitively-gated place? The role of need for closure in a biased perception of the place's past
}

\author{
Anna Wnuk ${ }^{1} \cdot$ Tomasz Oleksy $^{2} \cdot$ Sabina Toruńczyk-Ruiz ${ }^{2}$ \\ Published online: 12 June 2019 \\ (C) The Author(s) 2019
}

\begin{abstract}
Biased memory of the past is often a starting point for intergroup conflicts. In three correlational studies, we examined the relationship between need for closure (NFC) and historical ethnocentric bias, a tendency to overestimate the role of one's ethnic group in the multicultural history of the city of residence. In addition, we checked whether this relationship would be mediated by an individual preference for essentialist places. We found that higher NFC was related to increased historical ethnocentric bias. Moreover, this relation was mediated by preference for an essentialist type of a place. Our results may contribute to understanding the role of individual differences and preferred type of place in shaping a biased representation of the past. Furthermore, our research findings point to the importance of raising awareness of the multicultural past among high NFC individuals.
\end{abstract}

Keywords Need for closure $\cdot$ Representation of history $\cdot$ Essentialist place $\cdot$ Collective memory $\cdot$ Ethnocentrism $\cdot$ Biased perception · Place memory

\section{Introduction}

The tendency to overestimate personal contribution to joint efforts is a well-known cognitive bias (Gilovich et al. 2000; Ross and Sicoly 1979). Numerous studies have shown that individuals' estimations of their own responsibility for an ingroup's output sums up to more than $100 \%$, which is logically impossible (e.g., Schroeder et al. 2016; Thompson and Kelley 1981). Similar biases can apply to collective entities such as ethnic groups or nations, influencing the assessment of the group's role in shaping the history of the community of

Electronic supplementary material The online version of this article (https://doi.org/10.1007/s12144-019-00310-0) contains supplementary material, which is available to authorized users.

Anna Wnuk

anna.wnuk@psych.uw.edu.pl

Tomasz Oleksy

tomasz.oleksy@psych.uw.edu.pl

Sabina Toruńczyk-Ruiz

storunczyk@psych.uw.edu.pl

1 Department of Psychology, Nicolaus Copernicus University in Toruń, Toruń, Poland

2 Faculty of Psychology, University of Warsaw, Warsaw, Poland which they are part: villages, cities, countries, or even the world (Putnam et al. 2018).

Studies by Lewicka $(2008,2011)$ showed that residents of currently monoethnic cities with a multicultural past tend to overestimate the role of their own ethnic group in the place's history, while neglecting the role of other groups of previous residents. Lewicka refers to this biased perception of place's past as "historical ethnocentric bias". Recent research has shown that e.g., Americans tend to overestimate the significance of their home state in the U.S. history (Putnam et al. 2018), and a similar phenomenon was shown in a study on the perceived contribution of one's home country to world history (Zaromb et al. 2018).

There are several functions of such a biased representation of the past. First, overestimating the role of one's ethnic group legitimizes its dominance in the given territory and preserves collective self-esteem and identity (see e.g., Liu and Hilton 2005). Second, biased historical narratives are often deliberately used in the national discourse to legitimize one's ethnic or national group as the only rightful owner of the place, and to justify the denial of the outgroup's rights to that place. As research shows, biased place memory is often a flashpoint for intergroup conflicts (e.g., Conflict in Cities Research Group 2012; Dumper 2014). Overestimating the importance of one's group may be a potential cause of hostile behaviours towards outgroup members (Golec de Zavala et al. 2016; Putnam et al. 2018) and support for populist movements, which is 
increasing in the modern world (Marchlewska et al. 2018). Therefore, it is crucial to study the psychological mechanisms underlying such a biased representation of the place's past.

In this paper, we analyse data from three studies- two conducted in Poland and one in Israel - to investigate the individual, cognitive dispositions that may contribute to historical ethnocentric bias. Specifically, we analyse Need for Cognitive Closure (NFC) as a predictor of historical ethnocentric bias. We also try to identify a mediating factor of this relationship, which encompasses individual preferences regarding the type of place that people value and would like to live in. Individual preference of an essentialist place is a construct that we developed elsewhere (Wnuk et al. 2019), based on a concept of place as a meaningful location developed within human geography - an essentialist place understood as a stable, unchangeable and bounded space (Relph 1976; Tuan 1974, 1977).

\section{Need for Cognitive Closure and Historical Ethnocentric Bias}

In many recent inter-group disputes over the territory, we have seen recourse to history (Conflict in Cities Research Group 2012). What is remembered and what is forgotten from intergroup history very often legitimizes the group's reasoning in the conflict over a city, region or country. The celebration of major events, maintaining social rituals, emphasizing the importance of certain commemorations very often become key hotspots in the conflict over place (Páez and Liu 2011; Zerubavel 2003). The "policy of remembrance" is often the basis for current attitudes and claims, justifies the current social order and influences how the groups see and interpret various contemporary events (Figueiredo et al. 2017; Licata and Mercy 2015; Liu and Hilton 2005; Zerubavel 2003). In the territory of the former Yugoslavia, monuments commemorating the civil war have emphasized Croatian victimhood, and are used to remind the Serbian community its guilt; in Cyprus the political narrative on the Greek/Turkish victimization fuels the current Greek-Turkish conflict (Conflict in Cities Research Group 2012). The same process is also true in places that are nowadays monoethnic, but had been multicultural. This is particularly the case in the countries of Central and Eastern Europe, where national borders changed several times in the nineteenth and twentieth centuries and as a result, cities would change their national composition. For this reason, there are often parallel or contradictory visions of the past in the public debate, which makes it impossible to come to an agreement on common content of collective memory (see Lewicka 2012).

In line with historical literature (Baumeister and Hastings 1997; Connerton 2008), psychological research on the perception of the group's past has shown that people's memories generally tend to be biased: while some events and historical facts are remembered, some are absent, and some are deliberately "forgotten" to follow existing policy objectives (Leach et al. 2013; Lewicka 2008; Liu and Hilton 2005). One source of such distortions lies in social-psychological processes related to group favouritism, namely the egocentric tendency to favour one's own group over others (e.g., Molenberghs 2013; Verkuyten 2007). Based on data from Poland and Ukraine, Lewicka (2012) revealed that an overestimation of the role played by one's own ethnic group in the city's multicultural history (i.e. historical ethnocentric bias) was positively correlated with the strength of national identity and might be seen as a defensive reaction to preserve the national, homogeneous character of the given place. Therefore, people who strongly identify with their national group show stronger distortion of collective memory about their city of residence to legitimize that group's right to the city. Moreover, stronger endorsement of historical ethnocentric bias may be present when the national character of the residence place is perceived as threatened and needs to be secured. Partial support for this claim is offered by Smeekes et al. (2017), who showed that when group identity is threatened, group members are more likely to endorse a historical narrative that emphasizes their point of view in order to maintain a sense of collective continuity.

Historical ethnocentric bias may also result from cognitive processes like stereotyping and heuristic thinking, which avoid contradictory information and are focused on simple, one-sided representations (Lewicka 2011, 2012). Overestimation of the group's contribution to the place's history can be caused by the availability heuristic (Tversky and Kahneman 1973), because people generally have better access to information about the history of their own group than that of other groups, even if they had inhabited the given place in the past. They visit museums, learn history and celebrate national holidays which most often focus on the commemoration of the ingroup's role. According to the heuristic-systematic model of information processing (Chaiken and Ledgerwood 2011), in the heuristic mode of thinking people minimize their use of cognitive resources and are more apt to rely on easily noticed and understandable cues. In case of places with a multicultural past, it means overestimating the role of one's ethnic or national group in this past at the cost of other groups, and appears as consistent with the representation of the current situation, in which there is one dominant ethnic group. Meanwhile, openness to inconsistent information should be related to a complex mode of social representations (i.e. systematic mode of thinking), in which various features of the place are acknowledged (Lewicka 2011).

In this paper we argue that as an individual disposition connected with a need for stability and predictability, Need for Closure (NFC) can account for some of the variability in historical ethnocentric bias. NFC is a preference for clarity and certainty, and thus may be treated as a motivation to maintain 
epistemic security. Individuals with a strong NFC prefer certain information about the surrounding world with the aim to reduce cognitive efforts intrinsically related to dealing with ambiguity. In contrast, individuals low in NFC are more comfortable with ambiguity, and need more time to validate the information before arriving at a certain conclusion (Webster and Kruglanski 1994).

NFC influences the creation and use of cognitive schemas and stereotypes, determining the way people think and act in the real environment (Kossowska et al. 2015; Kossowska et al. 2018). Reliance on acquired mental schemas causes biases in search and use for information, leading high NFC individuals to omit facts that contradict established knowledge. This process, known as "cognitive gating" (Roets et al. 2015) prevents from feeling discomfort when confronting unexpected or ambiguous situations. According to Kruglanski and Webster (1996), cognitive gating consists of two subsequent steps: 1) seizing, crucial for determining which piece of information from the environment will be acquired, and 2) freezing, the stopping mechanism of the validation process. Individuals high in NFC tend to seize and freeze on information faster than these low in NFC (Kossowska 2006; Roets et al. 2015). High NFC is connected with a heuristic and top-down processing style, and may encourage an individual to overuse his or her biases, easily-accessible stereotypes and pre-existing attitudes, what leads to ignoring the case-specific or individuating information in forming a judgment (Kruglanski and Webster 1996; Perry and Sibley 2013).

As research has shown, NFC has important implications for real-life situations. According to numerous studies, NFC is related to political judgements and social beliefs, such as authoritarianism and conservatism (De Keersmaecker et al. 2016; Kossowska and Van Hiel 2003), as well as prejudice towards minority groups (Roets and Van Hiel 2011a), the degree of ingroup favouritism and outgroup derogation, and a desire for a homogeneous social environment (Roets et al. 2015). In addition, people high in NFC perceive their ingroup as more homogeneous than do those low in NFC (Dijksterhuis et al. 1996; Kruglanski and Mayseless 1988). Moreover, NFC has important implications for cultural formation, norm transmission and - in consequence - the development of shared reality (e.g., Dugas and Kruglanski 2018; Livi et al. 2015b). Research has shown that high NFC is related to maintenance of cultural norms via e.g., increasing conformity to norms and beliefs of older generations and this process can potentially lead to different forms of ingroup biases (Livi et al. 2015a).

Building on the above, we assume that NFC may also play a role in the perception of the place's past. Specifically, individuals high in NFC who tend to rely on heuristic thinking, simplified beliefs and preference for social homogeneity, can be expected to perceive the place's past based on the current version of the place. In cities and towns with a clear ethnic majority population, this would mean that ethnic majority members high in NFC should overestimate the role of their (currently dominant) ethnic group in the city's history, i.e. show greater historical ethnocentric bias than people low in NFC.

\section{Need for Cognitive Closure and Preference for Type of Place}

In this research, we propose that one possible mediator between NFC and historical ethnic bias is the preference for essentialist type of places, understood as stable, calm, coherent sites. Places are attributed with different meanings encompassing personal experience, an individual and emotional relation, a social sense of place, and historical and cultural significance (see e.g., Lewicka 2012). Research has demonstrated that places fulfil personal needs and facilitate selfdevelopment (Scannell and Gifford 2010; Searles 1960; Twigger-Ross and Uzzell 1996). As Wallenius (1999) showed, perceived supportiveness of the environment is associated with life satisfaction, and people consciously choose places that help them meet their everyday goals (see also Manzo 2003). Places provide people with safety or challenge, stability or excitement and have other functions that support individual needs or desired activities. By fulfilling homeostatic or heterostatic needs (Lewicka 2012) places may be used for self-regulatory purposes (Korpela and Hartig 1996) and thus preference for a certain type of place could differ according to individual traits and desires.

This paper assumes that people may differ in their preferences for places in terms of the place's stability, constancy, homogeneity and historical continuity. Some people prefer essentialist places: stable, static, unchangeable, defined through its uniqueness and historical continuity (Relph 1976; Tuan 1974, 1977; for an overview see Cresswell 2014; Malpas 2018), while others might prefer antiessentialist ones whose identity is not historically established: dynamic, diverse, constantly created through interaction, new arrivals, and strangers in the city (Massey 1991, 1994).

We want to emphasize that essentialist theories of place to which we refer in this paper are mostly based on the work of geographers and architects with a phenomenological background (Buttimer 1980; Relph 1976; Tuan 1977), and represent a slightly different approach to essentialism than that represented in social and developmental psychology (Davoodi et al. 2019; Gelman 2013; Haslam et al. 2004). In the geographical literature, place is defined as a set of features such as authenticity (Relph 1976), uniqueness (Casey 1997; Norberg-Schulz 1980), enclosure (Norberg-Schulz 1980; Tuan 1977), meaningfulness (Tuan 1977) and, to a lesser extent, "naturalness" (see e.g., Cresswell 2014). However, these theories are in many aspects consistent with the understanding 
of essentialism proposed by researchers in the field of social psychology, where essentialism is understood as the belief that members of certain categories share an innate, immutable and unobservable "essence" (Gelman 2003; Haslam et al. 2000; Medin and Ortony 1989; Rothbart and Taylor 1992). Essentialist categories differ from other categories in their stability over time, clear boundaries and high inductive potential, which enables inferring further qualities of the given category.

We expect that as an individual disposition relating to safety and potential changes in the place's character, preference for the type of place could mediate the relation between NFC and historical ethnocentric bias. We argue that, on the one hand, high NFC understood as a need for stability, nonambiguous and predictable situations, is related to preference for essentialist places, which are perceived as cohesive, stable and unchangeable entities. This argument is partially supported by the results of Roets and Van Hiel (2011b), who have shown that the degree to which people have essentialist beliefs could be explained by a more general motivation to have certain knowledge about the surrounding reality. They provided experimental evidence for the impact of NFC on essentialist beliefs and the effect of essentialist beliefs, in turn, on racial prejudice. We expect that high NFC could have a similar effect on the preference for an essentialist type of place, characterized by a strong sense of homogeneity and low level of complexity.

Importantly, we do not explicitly measure the individual tendency to treat a given place as an essential category but we focus on preference for essentialist places, which we define as having distinctive essentialist features such as stability, security and enclosure. We assume that such a preference, although related to places in general, may lead to the essentialisation of the place of residence - a process aimed at maintaining a stable, coherent image of that place. Indirect evidence for this claim comes from numerous studies on motivated information processing, which suggest that preexisting preferences affect the selection and perception of information (e.g., Baumeister and Newman 1994; Meffert et al. 2006; Van Bavel and Pereira 2018). This line of research showed that people tend to adjust the surrounding reality to their preferences, for instance through selection of information that confirms their opinions. High NFC individuals can be expected to have a preference for essentialist, unchangeable places, since living in such places would give protection from feeling discomfort of ambiguity and confrontation with a complex context. People who prefer an "essentialist" version of their area of residence, in turn, can be expected to be less likely to recognize its multicultural past than those without such a preference. This can be attributed to the perception of the place history in terms of its essentialist continuity: a vision of a stable, immutable city implies its stable and immutable past. Specifically, stronger endorsement of an essentialist view of an ideal place is likely to modify the representation of the residence place's past, i.e. to adjust the view of this past to an essentialist vision of an ideal place. In other words, we argue that the multicultural past of a current residence place may be essentialized in order to be compatible with one's preferred type of place and therefore it is perceived as more homogenous than it actually was. This relationship between the preferred type of place and historical ethnocentric bias was already confirmed in three studies (Wnuk et al. 2019).

\section{The Current Studies}

This paper expands the research on people-place relations by including Need for Cognitive Closure as a predictor of the representation of place's past and preference for type of place. We believe that this may provide a new approach to research on individual mechanisms underlying people-place relationships.

We tested our hypotheses in two different contexts: 1) selected Polish cities and towns that had previously been multicultural and are now relatively homogenous and 2) a city which has been multicultural for decades and is experiencing an ongoing intergroup conflict (Jerusalem). Most Polish cities, towns and villages have a rich and ethnically diverse history, but became ethnically homogenous in the aftermaths of World War II. In case of such places, acknowledging a multicultural past of a currently homogenous city may be threatening to epistemic security, because it means that the current worldview is subject to change (see also De Keersmaecker et al. 2016). Jerusalem, on the other hand, is a historically diverse city (Montefiore 2011), which at the same is polarized by the Jewish-Palestinian conflict about ethno-national identity and sovereignty (Calame and Charlesworth 2009; Gaffikin et al. 2010; Silver 2010). In such a contested city, acknowledging that the conflicted outgroup has contributed to the city's past may be ambiguous and confusing given the present situation. Thus, it contradicts simplistic, heuristic thinking which is typical for high NFC individuals. We therefore expected that in both Polish and Israeli contexts, NFC would be positively related to historical ethnocentric bias. In Study 3 we additionally check whether NFC is a unique predictor of historical ethnocentric bias independent from national identity, which is a known predictor of biased representation of place's past and may be particularly significant in the context of intergroup conflict.

In all studies, participants were from the ethnic majority group. Although the research samples were not representative, they covered persons of different ages and education levels. 


\section{Method}

\section{Participants}

Study 1 was conducted among young Polish residents of Cracow. We chose this place because Cracow, the former capital of Poland, is a traditional city with a fully preserved renaissance old town and unique medieval atmosphere, which, at the same time, is one of the largest academic centres in Poland - full of students, tourists and cultural events. Therefore, it is a place that fulfils different psychological place-related needs. Two hundred and eighty-eight persons $\left(74.7 \%\right.$ women, $25.3 \%$ men, $M_{\text {age }}=26.78$, $\left.S D_{\text {age }}=7.70\right)$ participated in an online study, of which $55 \%$ completed university education, $40 \%$ graduated from high school, and 5\% completed vocational training.

In Study 2, we examined the robustness of our results in a broader context of different cities and towns in Poland. The sample consisted of 206 persons ( $45.6 \%$ women, $54.4 \%$ men) of different age $\left(M_{\text {age }}=38.79, S D_{\text {age }}=17.55\right)$ and levels of education $(57 \%$ had a university degree, $43 \%$ completed either high school or vocational training). The mean length of residence in the city/town was 24.3 years $(S D=17.34)$. Participants were inhabitants of different regions in Poland (altogether 59 different villages, towns and cities).

Study 3 was conducted in Jerusalem via an Israeli internet panel. Quota sampling was used with quotas based on the gender and age composition of the general Jerusalem population. The study was conducted in Hebrew. One hundred Jewish-Israeli residents of Jerusalem (51 women, 49 men, $\left.M_{\text {age }}=44, S D_{\text {age }}=9.53\right)$ participated in the study. The mean length of residence in Jerusalem was $31.13(S D=15.53)$. On average, the participants had completed 15.2 years of education $(S D=2.69)$.

\section{Procedure}

In Study 1, the online questionnaire was distributed through different websites and web-groups. Participants were offered a possibility of compensation (participation in a drawing of five vouchers worth c.a. 10\$). In Study 2, participants were recruited by trained students of psychology during their holiday visits to their home towns. Each participant completed a paper questionnaire on their own, and had been assured that their responses would be treated confidentially and used for research purposes only. Study 3 was conducted by a professional research company, which maintains a database of people who can be approached for a survey. Participants completed an online questionnaire for a small compensation. In each study, participants were informed about the general topic of the research and were provided with all information required by the faculty ethics review panel. All participants gave their permission to be part of the study. The research procedures were also accepted by the faculty's scientific research ethics committee.

\section{Measures}

The measures used in three studies were the same, except for the measure of national identification (included only in Study 3 ). In the two online studies the measures were presented in a random order.

Need for Closure (NFC) Need for closure was measured with three subscales of a shortened version of the Need for Closure Scale (Kossowska et al. 2012) chosen due to their theoretical relevance to the study. The chosen subscales were: preference for order, preference for predictability and intolerance of ambiguity. Since the closedmindedness and decisiveness subscales were seen as related to a different underlying process and tap into the ability construct as well (Roets and Van Hiel 2007), they were not included in our analyses (see also Kossowska et al. 2002; Roets et al. 2006). The external validity of the shortened scale was supported by its positive correlations with Right-wing Authoritarianism, or Social Dominance Orientation (Kossowska et al. 2012). Several studies proved high reliability of the scale (Kossowska et al. 2015; Kossowska et al. 2012), and this was the case also in our samples, $\alpha=.86, \alpha=.88$ and $\alpha=.89$ in Studies 1, 2 and 3, respectively.

Preference for an essentialist type of place was measured by six items designed by Wnuk and colleagues (Wnuk et al. 2019). The respondents were asked to think of their ideal version of the city of residence, and answer whether or not they agreed with statements such as "[My ideal city] is a quiet and secluded place", "... allows to isolate from the world", “... is a traditional place". In Studies 1 and 2 the response scale was changed to a 5-point scale (from $1=$ strongly disagree to $5=$ strongly agree). In the third study participants marked whether each statement applied to their preferred meaning of place on a nominal scale $(1=$ Yes, $0=$ No and $9=$ Don't know). In our analyses, we treated "don't know" answers as missing values (however, we performed additional analysis with this variable treated as a continuous one, with the responses coded as follows: $1=$ No, $2=$ Don't know, $3=$ Yes, see the Appendix). he measure used in the analyses was the mean of the six items (in Studies 1 and 2) and the ratio of "yes" responses to all six items, with the missing values excluded in a pairwise manner (Study 3). The reliability of the scale was $\alpha=.60$ in Study 1, .58 in Study 2, and .64 in Study 3. 
Table 1 Means, range, and standard deviations of the key variables

\begin{tabular}{|c|c|c|c|c|c|c|}
\hline & \multicolumn{2}{|l|}{ Study 1} & \multicolumn{2}{|l|}{ Study 2} & \multicolumn{2}{|l|}{ Study 3} \\
\hline & $M$ & $S D$ & $M$ & $S D$ & $M$ & $S D$ \\
\hline Preference for an essentialist place & $2.98(1-5)$ & 0.67 & $3.12(1-5)$ & 0.64 & $0.32(0 / 1)$ & 0.20 \\
\hline Historical ethnocentric bias & $3.71(1-5)$ & 0.95 & $3.65(1-5)$ & 0.85 & $4.79(1-7)$ & 1.67 \\
\hline Need for closure & $3.71(1-6)$ & 0.98 & $4.31(1-6)$ & 0.92 & $5.01(1-7)$ & 1.18 \\
\hline
\end{tabular}

Historical ethnocentric bias was measured with a subscale of the Perceived Ethnic Continuity Scale - Ethnocentrism (Lewicka 2012), which consists of three items relating to the role of representatives of other nationalities in a given place's past, in this case this was the city/town of residence (e.g., "Poles were always the most important national group in Cracow"). The subscale was suitable for our study, since a high score indicates a stronger historical ethnocentric bias in the representation of the place's past. The items were rated on a 5-point scale (from 1 = strongly disagree to $5=$ strongly agree). Previous studies proved good reliability of the scale (Lewicka 2012). The external validity of the shortened scale was supported by its positive correlations with such measures as the "Polish meaning of the residence place" and the estimation of pre-war Polish population in the residence place (higher historical ethnocentric bias was associated with a higher overestimation of the number of Poles before World War II). The reliability of the scale in our studies was $\alpha=.71, \alpha=.59$ and $\alpha=.81$ in Studies 1,2 and 3, respectively. In the Appendix we present additional analyses of the reliabilities of the Historical ethnocentric bias and Preference for an essentialist type of place scales for Study.

National identification was measured with six items of the Social Identity Scale (Cameron 2004), e.g., "Generally, I feel good when I think about myself as an Israeli". This scale has been shown to have good psychometric properties in previous studies (e.g., Cameron 2004; Obst and White 2005). Participants answered on a scale from $1=$ strongly disagree to $7=$ strongly agree. The reliability of the scale in the present study was $\alpha=.89$.

In addition to the variables mentioned above, we collected information on socio-demographic characteristics such as age, gender, education level and length of residence in the city/town. In each study, participants provided these at the end of the questionnaire.
All analyses were done with SPSS 24. To test whether the relation between NFC and historical ethnic bias would be mediated by preference for an essentialist type of a city/town, we used bootstrapping in PROCESS v. 3.1 (Hayes 2017) with 10,000 bootstrap samples (model 4). In all studies we controlled for age and level of education. The means and standard deviations of the key variables in each study are presented in Table 1.

\section{Results}

Because we test the same relationships in all three studies, we present our analyses including the results from all studies.

Zero-order correlations between the studied variables are presented in Table 2. In all three studies, NFC was significantly and positively related to preference for an essentialist place and to historical ethnocentric bias. Preference for an essentialist place was, in all studies, significantly and positively related to ethnocentrism.

The results of the analyses of Study 1 indicate that the indirect effect of NFC on ethnic bias via the preference for essentialist place was statistically significant with a $95 \%$ bootstrap confidence interval $(\mathrm{CI})$ ranging from 0.01 to $0.09, \beta=$ $0.04, S E=0.02$. In Study 2, the 95\% CI ranged from 0.01 to $0.10 ; \beta=0.05, S E=0.02$. In Study 3 we additionally controlled for national identity. The indirect effect of preference for essentialist place was significant with a $95 \%$ CI from 0.01 to $0.26 ; \beta=0.08, S E=0.04$. The standardized coefficients of the model are presented in Fig. 1.

The results of alternative analyses, which tested mediation models with different ordering of the three variables are included in the Appendix.
Table 2 Zero-order Correlations (Study 1/ Study 2/ Study 3)

\begin{tabular}{lll}
\hline & NFC & Preference for an essentialist place \\
\hline Preference for an essentialist place & $.15^{* *} / .23^{* *} / .27^{*}$ & - \\
Historical ethnocentric bias & $.15^{* *} / .16^{*} / .32^{* *}$ & $.25^{* *} / .26^{* *} / .36^{* *}$ \\
\hline
\end{tabular}

Notes: ${ }^{*} p<.05,{ }^{* *} p<.01$ 


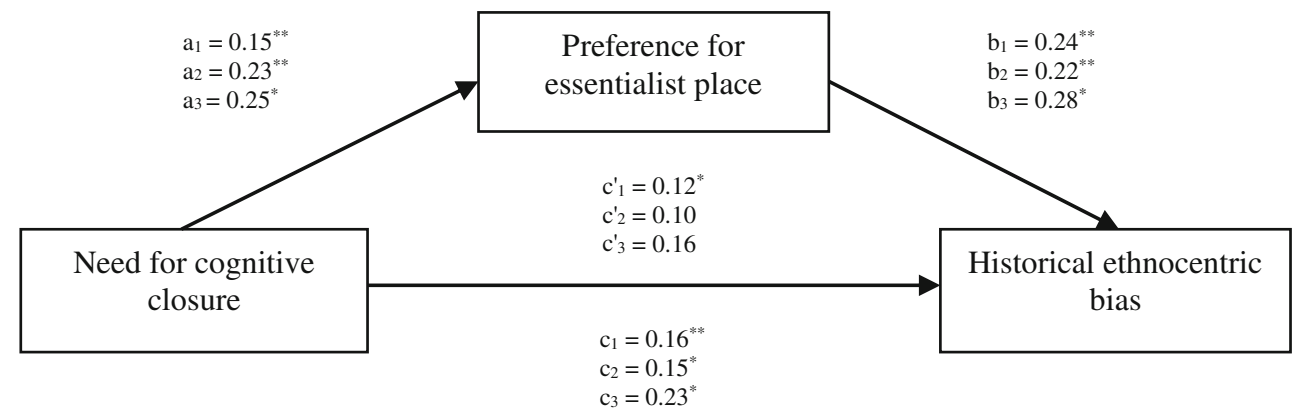

Fig. 1 Relationships between NFC, preference for an essentialist place and historical ethnocentric bias in the three studies. Notes: $a$ represents the effect of NFC on the preference for an essentialist place, $b$ is the effect

\section{Discussion}

The main aim of our paper was to examine the relationship between individual need for cognitive closure and historical ethnocentric bias, the latter referring to an overestimation of one's ethnic group in the place's multicultural past. We hypothesized that NFC would be positively related to ethnocentric bias, and that this relation would be partially explained by a preference for an essentialist type of place. To increase the generalizability of our results, we conducted studies in different contexts: Study 1 was done in a large Polish city with a renowned multicultural past which now is homogenous, Study 2 - in a diverse sample of residents from Polish cities and towns of different sizes, with different educational levels and ages, and Study 3 - in a heterogeneous and conflicted city, namely Jerusalem.

All three studies confirmed that NFC was positively linked with historical ethnocentric bias. This is consistent with the proposed mechanism underlying ethnocentric bias, based on the processes of stereotyping and heuristic thinking (Lewicka 2011). Previous research has shown that people high in NFC tend to avoid contradictory information and instead rely on heuristic thinking (Roets et al. 2015). To our knowledge, ours is the first study to show that people high in NFC may be especially prone to be biased in their representation of a place's past. Thus, our results may help understand individual differences that shape a biased perception of the past, which is often the root of severe intergroup conflicts. In our view, our Studies 1 and 2 could suggest that residents of currently mono-ethnic cities and towns who are high in NFC may tend to rely on easily accessible information from the present, and are thus more prone to underestimate the significance of other ethnic groups in the history of their city or town. Study 3, conducted in a multiethnic city, suggests in turn that historical ethnocentric bias may be based on a motivational mechanism and tendency to avoid ambiguity of the heterogeneous past. We showed that the relation between NFC and historical ethnocentric bias holds true while controlling for national identity of preference for an essentialist place on ethnocentrism, $c$ is the total effect and $c^{\prime}$ is the direct effect of NFC on ethnocentrism (numbers accompanying letters refer to Studies 1,2 and 3 respectively)

- therefore NFC is a unique predictor and explains ethnocentric bias over and above national identification.

Our studies also demonstrated that the relationship between NFC and historical ethnocentric bias was mediated by a preference for an essentialist type of a place. Specifically, people high in NFC had a stronger preference for an essentialist place, which in turn was related to their biased view of the role of other ethnic groups in the place's history. We argue that people high in NFC are more likely to prefer essentialist places because these places fulfil the needs for a stable and less complex living environment. These needs in turn translate into an essentialist interpretation of that place's history, leading to a biased perception of the role of other ethnic groups in its past. Thus, NFC could be satisfied by reducing the complexity of the place's representation to a homogenous space, which throughout history has been inhabited by the ingroup. These findings correspond with modern concepts of place, which assume that essentialist places evoke boundaries between people and reduce openness towards residents from other ethnic groups (Harvey 1996). As our research shows, this applies not only to attitudes towards the present situation, but also to the past one.

In Study 1, conducted in Kraków (Poland), also the direct effect of NFC on historical ethnocentric bias remained positive and significant, which means that NFC was still related to historical ethnocentric bias after considering the mediating role of preference for an essentialist type of place. One explanation for this could be that NFC is known to induce the tendency to maintain existing knowledge, and as such it promotes resistance to change (Livi et al. 2015a, b). In a city that is a symbol of Polish national culture and - to some extent - is still a very traditional place, NFC may be related with a willingness to preserve national cultural values which are present in the city, and not only with the desire to live in a stable and secluded place (cf. Livi et al. 2015a, b). This willingness could thus function as another mediator of the positive relation between NFC and historical ethnocentric bias. Whether or not this is the case could be investigated in future work, which 
should also try to identify additional mechanisms underlying the association between NFC and historical ethnocentric bias.

While the results of our studies offer initial support of our hypotheses, they have some limitations. Since our studies are correlational, they do not allow us to establish causal relationships between the variables. It could be that preference for an essentialist type of place affects historical ethnocentric bias, or that the relation between the two is bidirectional. However, we assume that NFC as an individual disposition predicts preference for the type of ideal place and representation of the place's past rather than these two affecting NFC. Research on motivated information processing in turn showed that preferences affect the selection and perception of given information (e.g., Baumeister and Newman 1994; Festinger 1957). Based on this, we suggest that NFC affects place preference, which in turn influences the perception of the history of one's own residence place in order to adjust the identity of the current place of residence to the ideal one.

Another limitation is that our studies included only members of the ethnic majority group. Among the ethnic minorities, historical ethnocentric bias would mean maintaining a version of the past that overestimates the role of their own ethnic group. In this sense, the explanatory role of NFC and preference for an essentialist type of place could remain similar for these inhabitants. However, the strength of ethnocentric bias among members of ethnic minorities could be weaker than for the majority group members, and would naturally depend on whether these groups have actually inhabited the given place of interest. On the other hand, in a place of conflict, members of the ethnic minority group may be likely to show greater historical ethnocentric bias, since this serves as a legitimization of the group's right to this place. Future research is needed to investigate whether the patterns found in our studies hold in other contexts and populations, including members of ethnic minority groups.

A third limitation of our studies is the relatively low reliability of the scale measuring preference for an essentialist place (Cronbach alphas from .58 in Study 2 to .64 in Study 3 ). The lower reliability of the scale in Study 2 could be because of the very heterogeneous sample in this study, which included participants of different ages living in areas of different sizes. The individual vision of an ideal place of residence may be strongly determined by the spatial scale of the given setting, and thus future research should include studies conducted in different spatial contexts, including both larger cities and smaller towns and rural areas. Nevertheless, according to Kline (1999) in the context of psychological constructs, reliability values below even 0.7 can be expected because of the diversity of the constructs being measured. Lower reliability parameters may also result from using the 5-category Likert response format (Guilford 1956).
Despite the above limitations, our study reveals that individual differences may partially explain such social constructs as place-related ethnic bias and it is worth addressing them in future studies. Additionally, our results broaden the knowledge on people-place relations by showing the role of individual preference for an essentialist place in shaping the perception of the places' past. We believe that these studies provide a new approach to research on individual mechanisms underlying people-place relationships, as well as their cognitive and social consequences.

The mechanism shown in our study is particularly important in the context of the increasing popularity of populist movements and opposition towards immigrants and refugees across Europe and the U.S. Many governments successfully conduct a policy of fear (Capelos and Katsanidou 2018; Portice and Reicher 2018), and take advantage of the people's need for security by promising to make the country a "safe home" (e.g., Viktor Orban in Hungary or Sweden Democrats, see Mitzen 2018). For many people, home means a safe and familiar place. Thus, a sense of threat and uncertainty may cause an increase in the preference for an essentialist type of places and, subsequently, the motivation to perceive the home area as a stable and homogenous one. A side-effect of this process may result in biased perception of places' complex history and traces of the outgroups' contribution. Ignoring multicultural history may in turn translate into an even greater vulnerability to populist slogans that claim - incorrectly - that a country has always been a nationally homogeneous one or that the contribution of other groups to the country's development has been minimal. Therefore, at a practical level, our research findings point to the importance of raising awareness of the multicultural past among the institutions responsible for presenting history to the general public - city authorities, historical institutes or museums. We believe that commemoration of multicultural history in an attractive and engaging way could hamper both the preference-based essentialization of places and other potential mechanisms that foster the emergence of historical ethnocentric bias. Showing that a familiar place had been a multicultural one, in which various groups were able to jointly contribute to its development, could translate into a reduction of historical ethnic bias and reduce the tendency to associate the place's safety with its homogeneity.

Importantly, the commemoration of multiculturalism can be particularly beneficial for the reduction of historical ethnocentric bias among individuals with high NFC. As recent studies have demonstrated, these individuals do not always present less effort and commitment to information processing; conversely, in some circumstances they are able to engage in more complex and demanding thinking than people with low NFC (e.g., Jaśko et al. 2015; Szumowska et al. 2018; Viola et al. 2015). High NFC individuals are more open-minded and engage in more extensive information search than usual when their knowledge does not provide a sufficient basis for simplified thinking, or if 
the information obtained may call into question their ability to interpret the given situation correctly (Kossowska and Bar-Tal 2013; Kruglanski et al. 1991). However, this effect of increased openness is diminished when high NFC individuals do not engage enough cognitive resources in information processing (Strojny et al. 2016). Thus, commemoration of the multicultural past may result in undermining their belief in the exclusive role of their ingroup in the place's history, but the form of this commemoration should be engaging enough. For this reason, actions taken by city authorities or other institutions should not be limited to typical ways of commemorating the presence of other ethnic and national groups through monuments or street names, but should also include more engaging ways of restoring the past, such as through the use of virtual or augmented reality and historical walking tours (see e.g., Oleksy and Wnuk 2016; Wang and Kao 2017; Zamora-Musa et al. 2018). It is worth studying which methods of reducing historical ethnic bias are most effective, and which of them could counterbalance the effects of a preference for an essentialist type of place among high NFC individuals.

Acknowledgments Studies presented in this paper were financed by two grants from the Polish National Science Centre No 2013/11/N/HS6/ 01183, and No 2011/03/B/HS6/03320.

Preparation of the manuscript was supported by scholarships 2016/20/ T/HS6/00404 (TO), 2017/24/T/HS6/00292 (AW) and 2014/12/T/HS6/ 00487 (ST-R).

\section{Compliance with Ethical Standards}

Conflict of Interest On behalf of all authors, the corresponding author states that there is no conflict of interest.

\section{Appendix}

\section{Additional analyses of Study 3}

In Study 3, we run additional analyses with the mediator coded as a continuous variable that included the "don't know" category as the middle one $(1=$ No, $2=$ Don't know, $3=$ Yes $)$. The general pattern of the results remained the same as in our original model. The indirect effect of preference for essentialist place was positive and significant, with a $95 \% \mathrm{CI}$ from 0.04 to $0.29 ; \beta=0.14, S E=0.06$. The direct effect remained significant, $\beta=0.27, S E=0.13, p=0.04$.

\section{Alternative mediation models in Studies 1, 2 \&3}

We also estimated two alternative models, with a different ordering of variables.

First, we examined whether preference for essentialist place mediated the association between historical ethnocentric bias and NFC. In Study 1, the indirect effect as tested in such an alternative model was not significant, $\beta=0.03, S E=0.02$, $95 \%$ CI from -0.004 to 0.09 . In Study 2 , the indirect effect in the alternative model was significant, $\beta=0.04, S E=0.02$, $95 \%$ CI from 0.01 to 0.09 . In Study 3, the indirect effect was not significant, $\beta=0.08, S E=0.06,95 \%$ CI from -0.001 to 0.22 .

Additionally, we estimated a model with historical ethnocentrism as a mediator of the relation between NFC and preference for essentialist place. In all three studies, the indirect effect was positive and significant; $\beta=0.04, S E=0.02,95 \%$ CI from 0.005 to 0.05 in Study $1, \beta=0.03, S E=0.02,95 \% \mathrm{CI}$ from 0.004 to 0.06 in Study 2 , and $\beta=0.07, S E=0.04,95 \%$ CI from 0.001 to 0.18 , in Study 3 .

Although we are not able to establish causality with crosssectional data, we believe the results of the alternative models add additional support that NFC, which is a personal trait, predicts the latter two rather than being an outcome variable, making the first alternative model the least likely. The relation between place preference and historical ethnocentric bias may be bidirectional. However, based on theoretical reasoning, we find it more plausible that NFC predicts a more general place preference and this leads to a more particular bias regarding the past of the place of residence, as suggested by our original model (presented in Fig. 1).

\section{Additional analyses regarding the reliability of the scales}

Given the relatively low reliabilities of the place preference and historical ethnocentric bias scales in Study 2, we run additional analyses for a more homogeneous sample of respondents. The reliability for the place preference scale calculated for the subsample of participants from large cities was higher, $\alpha=.61$. In case of historical ethnocentrism, the reliability of the scale was lowered by one item ("In school curriculum Polish history of my city/town/village should be emphasized") without which the reliability was higher, $\alpha=.71$. Given the theoretical relevance of this item for the historical ethnocentric bias construct, we decided not to exclude this item from the scale. When we performed the mediation analysis with the variable that excluded this item, we found the same pattern of results, with the indirect effect positive and significant at point $\beta=0.06, S E=0.02$, CI from 0.02 to 0.12 .

Open Access This article is distributed under the terms of the Creative Commons Attribution 4.0 International License (http:// creativecommons.org/licenses/by/4.0/), which permits unrestricted use, distribution, and reproduction in any medium, provided you give appropriate credit to the original author(s) and the source, provide a link to the Creative Commons license, and indicate if changes were made. 


\section{References}

Baumeister, R. F., \& Hastings, S. (1997). Distortions of collective memory: How groups flatter and deceive themselves. In J. W. Pennebaker, D. Paez, \& B. Rimé (Eds.), Collective memory of political events: Social psychological perspectives (pp. 277-293). Hillsdale: Lawrence Erlbaum Associates, Inc..

Baumeister, R. F., \& Newman, L. S. (1994). Self-regulation of cognitive inference and decision processes. Personality and Social Psychology Bulletin, 20(1), 3-19. https://doi.org/10.1177/ 0146167294201001.

Buttimer, A. (1980). Home, reach, and the sense of place. In A. Buttimer $\&$ D. Seamon (Eds.), The human experience of space and place (pp. 166-187). New York: St Martins Press. https://doi.org/10.4324/ 9781315684192.

Calame, J., \& Charlesworth, E. (2009). Divided cities Belfast, Beirut, Jerusalem, Mostar, and Nicosia. Philadelphia: University of Pennsylvania Press.

Cameron, J. (2004). A three factor model of social identity. Self and Identity, 3(3), 239-262. https://doi.org/10.1080/ 13576500444000047.

Capelos, T., \& Katsanidou, A. (2018). Reactionary politics: Explaining the psychological roots of anti preferences in European integration and immigration debates. Political Psychology, 39(6), 1271-1288. https://doi.org/10.1111/pops.12540.

Casey, E. (1997). The fate of place: A philosophical history. Berkeley: University of California Press.

Chaiken, S., \& Ledgerwood, A. (2011). A theory of heuristic and systematic information processing. Handbook of theories of social psychology: Volume one, 246-166.

Conflict in Cities Research Group. (2012). The politics of heritage: Why memory in divided cities impacts upon the future, Conflict in Cities Briefing Paper No.8. Retrieved from www.conflictincities.org.

Connerton, P. (2008). Seven types of forgetting. Memory Studies, 1(1), 59-71. https://doi.org/10.1177/1750698007083889.

Cresswell, T. (2014). Place: An introduction. John Wiley \& Sons.

Davoodi, T., Soley, G., Harris, P. L., \& Blake, P. R. (2019). Essentialization of social categories across development in two cultures. Child Development. https://doi.org/10.1111/cdev.13209.

De Keersmaecker, J., Van Assche, J., \& Roets, A. (2016). Need for closure effects on affective and cognitive responses to culture fusion. Journal of Cross-Cultural Psychology, 47(10), 1294-1306. https:// doi.org/10.1177/0022022116666375.

Dijksterhuis, A. P., Van Knippenberg, A. D., Kruglanski, A. W., \& Schaper, C. (1996). Motivated social cognition: Need for closure effects on memory and judgment. Journal of Experimental Social Psychology, 32(3), 254-270. https://doi.org/10.1006/jesp.1996. 0012 .

Dugas, M., \& Kruglanski, A. W. (2018). Shared reality as collective closure. Current Opinion in Psychology, 23, 72-76. https://doi.org/ 10.1016/j.copsyc.2018.01.004

Dumper, M. (2014). Jerusalem unbound: Geography, history, and the future of the Holy City. Columbia University Press.

Festinger, L. (1957). A theory of cognitive dissonance. Evanston: Row, Peterson

Figueiredo, A., Martinovic, B., Rees, J., \& Licata, L. (2017). Collective memories and present-day intergroup relations: Introduction to the special thematic section. Journal of Social and Political Psychology, 5(2), 694-706. https://doi.org/10.5964/jspp.v5i2.895.

Gaffikin, F., Mceldowney, M., \& Sterrett, K. (2010). Creating shared public space in the contested city: The role of urban design. Journal of Urban Design, 15(4), 493-513. https://doi.org/10.1080/ 13574809.2010.502338.
Gelman, S. A. (2003). The essential child: Origins of essentialism in everyday thought. Oxford Series in Cognitive Dev. https://doi.org/ 10.5860/choice.41-1239.

Gelman, S. A. (2013). Artifacts and essentialism. Review of Philosophy and Psychology, 4(3), 449-463. https://doi.org/10.1007/s13164013-0142-7.

Gilovich, T., Medvec, V. H., \& Savitsky, K. (2000). The spotlight effect in social judgment: An egocentric bias in estimates of the salience of one's own actions and appearance. Journal of Personality and Social Psychology, 78(2), 211-222. https://doi.org/10.1037//0022-3514. 78.2.211

Golec de Zavala, A., Peker, M., Guerra, R., \& Baran, T. (2016). Collective narcissism predicts hypersensitivity to ingroup insult and direct and indirect retaliatory intergroup hostility. European Journal of Personality, 30(6), 532-551. https://doi.org/10.1002/ per.2067.

Guilford, I. P. (1956). Psychometric methods. New York: McGraw-Hill.

Harvey, D. (1996). Justice, nature and the geography of difference. Oxford: Blackwell.

Haslam, N., Rothschild, L., \& Ernst, D. (2000). Essentialist beliefs about social categories. British Journal of Social Psychology, 39(1), 113127. https://doi.org/10.1348/014466600164363.

Haslam, N., Rothschild, L., \& Ernst, D. (2004). Essentialism and Entitativity: Structures of beliefs about the ontology of social categories. In V. Yzerbyt, C. M. Judd, \& O. Corneille (Eds.), The psychology of group perception (pp. 61-78). New York: Psychology Press.

Hayes, A. F. (2017). Introduction to mediation, moderation, and conditional process analysis: A regression-based approach. Guilford Press.

Jaśko, K., Czernatowicz-Kukuczka, A., Kossowska, M., \& Czarna, A. Z. (2015). Individual differences in response to uncertainty and decision making: The role of behavioral inhibition system and need for closure. Motivation and Emotion, 39(4), 541-552. https://doi.org/ 10.1016/j.paid.2014.06.013.

Kline, P. (1999). The handbook of psychological testing (2nd ed.). London: Routledge.

Korpela, K., \& Hartig, T. (1996). Restorative qualities of favorite places. Journal of Environmental Psychology, 16(3), 221-233. https://doi. org/10.1006/jevp.1996.0018.

Kossowska, M. (2006). Motivational and cognitive antecedents of political beliefs. Polish Psychological Bulletin, 3(37), 133-144.

Kossowska, M., \& Bar-Tal, Y. (2013). Need for closure and heuristic information processing: The moderating role of the ability to achieve the need for closure. British Journal of Psychology, 104(4), 457480. https://doi.org/10.1111/bjop.12001.

Kossowska, M., \& Van Hiel, A. V. (2003). The relationship between need for closure and conservative beliefs in Western and Eastern Europe. Political Psychology, 24(3), 501-518. https://doi.org/10.1111/0162895X.00338.

Kossowska, M., Van Hiel, A., Chun, W. Y., \& Kruglanski, A. W. (2002). The need for cognitive closure scale: Structure, cross-cultural invariance, and comparison of mean ratings between European-American and east Asian samples. Psychologica Belgica, 42(4), 267-286.

Kossowska, M., Hanusz, K., \& Trejtowicz, M. (2012). Skrócona wersja Skali Potrzeby Poznawczego Domknięcia. Dobór pozycji i walidacja skali. Psychologia Społeczna, 1(20), 89-99.

Kossowska, M., Dragon, P., \& Bukowski, M. (2015). When need for closure leads to positive attitudes towards a negatively stereotyped outgroup. Motivation and Emotion, 39(1), 88-98. https://doi.org/10. 1007/s11031-014-9414-5.

Kossowska, M., Szumowska, E., Dragon, P., Jaśko, K., \& Kruglanski, A. W. (2018). Disparate roads to certainty processing strategy choices under need for closure. European Review of Social Psychology, 29(1), 161-211. https://doi.org/10.1080/10463283.2018.1493066. 
Kruglanski, A. W., \& Mayseless, O. (1988). Contextual effects in hypothesis testing: The role of competing alternatives and epistemic motivations. Social Cognition, 6(1), 1-21. https://doi.org/10.1521/soco. 1988.6.1.1.

Kruglanski, A. W., \& Webster, D. M. (1996). Motivated closing of the mind: "seizing" and "freezing". Psychological Review, 103(2), 263283.

Kruglanski, A. W., Peri, N., \& Zakai, D. (1991). Interactive effects of need for closure and initial confidence on social information seeking. Social Cognition, 9(2), 127-148. https://doi.org/10.1521/soco. 1991.9.2.127.

Leach, C. W., Zeineddine, F. B., \& Čehajić-Clancy, S. (2013). Moral immemorial: The rarity of self-criticism for previous generations' genocide or mass violence. Journal of Social Issues, 69(1), 34-53. https://doi.org/10.1111/josi.12002.

Lewicka, M. (2008). Place attachment, place identity, and place memory: Restoring the forgotten city past. Journal of Environmental Psychology, 28(3), 209-231. https://doi.org/10.1016/j.jenvp.2008. 02.001

Lewicka, M. (2011). Historical ethnic bias in collective memory of places: Cognitive or motivational? In W. B. G. Keren, G. Kirkeboen, \& H. Montgomery (Eds.), Perspectives on thinking, judging, and decision making (pp. 262-273). Universitetsforlaget.

Lewicka, M. (2012). Psychologia miejsca. (Psychology of place.) Warszawa: Wydawnictwo Naukowe Scholar

Licata, L., \& Mercy, A. (2015). Collective memory, social psychology of. In J. D. Wright (Ed.), International encyclopedia of the Social \& Behavioral Sciences (pp. 194-199). Oxford: Elsevier.

Liu, J. H., \& Hilton, D. J. (2005). How the past weighs on the present: Social representations of history and their role in identity politics. British Journal of Social Psychology, 44(4), 537-556. https://doi. org/10.1348/014466605X27162.

Livi, S., Kruglanski, A. W., Pierro, A., Mannetti, L., \& Kenny, D. A. (2015a). Epistemic motivation and perpetuation of group culture: Effects of need for cognitive closure on trans-generational norm transmission. Organizational Behavior and Human Decision Processes, 129, 105-112. https://doi.org/10.1016/j.obhdp.2014.09. 010

Livi, S., Pierro, A., Rullo, M., \& Kruglanski, A. (2015b). Motivational underpinnings of intergenerational transmission: The role of need for cognitive closure on salience of perceived norms. Journal of Cross-Cultural Psychology, 46(10), 1356-1360. https://doi.org/10. 1177/0022022115605902.

Malpas, J. (2018). Place and experience: A philosophical topography. Routledge.

Manzo, L. C. (2003). Beyond house and haven: Toward a revisioning of emotional relationships with places. Journal of Environmental Psychology, 23(1), 47-61. https://doi.org/10.1016/S0272-4944(02) 00074-9.

Marchlewska, M., Cichocka, A., Panayiotou, O., Castellanos, K., \& Batayneh, J. (2018). Populism as identity politics: Perceived ingroup disadvantage, collective narcissism, and support for populism. Social Psychological and Personality Science, 9(2), 151162. https://doi.org/10.1177/1948550617732393.

Massey, D. (1991). A global sense of place. Marxism Today, 38, 24-29.

Massey, D. (1994). Space, place and gender. Minneapolis: University of Minnesota Press.

Medin, D. L., \& Ortony, A. (1989). Psychological essentialism. In S. Vosniadou\& \& A. Ortony (Eds.), Similarity and analogical reasoning (pp. 179-195). New York: Cambridge University Press.

Meffert, M. F., Chung, S., Joiner, A. J., Waks, L., \& Garst, J. (2006). The effects of negativity and motivated information processing during a political campaign. Journal of Communication, 56(1), 27-51. https://doi.org/10.1111/j.1460-2466.2006.00003.x.
Mitzen, J. (2018). Feeling at home in Europe: Migration, ontological security, and the political psychology of EU bordering. Political Psychology, 39(6), 1373-1387. https://doi.org/10.1111/pops.12553.

Molenberghs, P. (2013). The neuroscience of in-group bias. Neuroscience \& Biobehavioral Reviews, 37(8), 1530-1536. https://doi.org/10. 1016/j.neubiorev.2013.06.002.

Montefiore, S. (2011). Jerusalem: The Biography. London: Weidenfeld \& Nicolson.

Norberg-Schulz, C. (1980). Genius loci: Towards a phenomenology of architecture. NewYork: Rizzoli.

Obst, P., \& White, K. (2005). Three-dimensional strength of identification across group memberships: A confirmatory factor analysis. Self and Identity, 4(1), 69-80. https://doi.org/10.1080/13576500444000182.

Oleksy, T., \& Wnuk, A. (2016). Augmented places: An impact of embodied historical experience on attitudes towards places. Computers in Human Behavior, 57, 11-16. https://doi.org/10.1016/j.chb.2015. 12.014 .

Páez, D., \& Liu, J. H. (2011). Collective memory of conflict. In D. BarTal (Ed.), Intergroup conflicts and their resolution: A social psychological perspective. New York - London: Psychology Press.

Perry, R., \& Sibley, C. G. (2013). Seize and freeze: Openness to experience shapes judgments of societal threat. Journal of Research in Personality, 47(6), 677-686. https://doi.org/10.1016/j.jp.2013.06.006.

Portice, J., \& Reicher, S. (2018). Arguments for European disintegration: A mobilization analysis of anti-immigration speeches by UK political leaders. Political Psychology, 39(6), 1357-1372. https://doi.org/ 10.1111/pops. 12551

Putnam, A. L., Ross, M. Q., Soter, L. K., \& Roediger, H. L., III. (2018). Collective narcissism: Americans exaggerate the role of their home state in appraising US history. Psychological Science. https://doi. org/10.1177/0956797618772504.

Relph, E. (1976). Place and Placelessness. London: Pion.

Roets, A., \& Van Hiel, A. (2011a). Allport's prejudiced personality today: Need for closure as the motivated cognitive basis of prejudice. Current Directions in Psychological Science, 20(6), 349-354. https://doi.org/10.1177/0963721411424894.

Roets, A., \& Van Hiel, A. (2011b). The role of need for closure in essentialist entitativity beliefs and prejudice: An epistemic needs approach to racial categorization. British Journal of Social Psychology, 50(1), 52-73. https://doi.org/10.1348/ $014466610 X 491567$.

Roets, A., \& Van Hiel, A. (2007). Separating ability from need: Clarifying the dimensional structure of the need for closure scale. Personality and Social Psychology Bulletin, 33(2), 266-280

Roets, A., Van Hiel, A., \& Cornelis, I. (2006). The dimensional structure of the need for cognitive closure scale: Relationships with "seizing" and "freezing" processes. Social Cognition, 24(1), 22-45.

Roets, A., Kruglanski, A. W., Kossowska, M., Pierro, A., \& Hong, Y. Y. (2015). Chapter four-the motivated gatekeeper of our minds: New directions in need for closure theory and research. Advances in Experimental Social Psychology, 52, 221-283. https://doi.org/10. 1016/bs.aesp.2015.01.001.

Ross, M., \& Sicoly, F. (1979). Egocentric biases in availability and attribution. Journal of Personality and Social Psychology, 37(3), 322336. https://doi.org/10.1037/0022-3514.37.3.322.

Rothbart, M., \& Taylor, M. (1992). Category labels and social reality: Do we view social categories as natural kinds? In G. R. Semin \& K. Fiedler (Eds.), Language, interaction and social cognition (pp. 1136). Thousand Oaks: Sage Publications, Inc..

Scannell, L., \& Gifford, R. (2010). Defining place attachment: A tripartite organizing framework. Journal of Environmental Psychology, 30(1), 1-10. https://doi.org/10.1016/j.jenvp.2009.09.006.

Schroeder, J., Caruso, E. M., \& Epley, N. (2016). Many hands make overlooked work: Over-claiming of responsibility increases with group size. Journal of Experimental Psychology: Applied, 22(2), 238-246. https://doi.org/10.1037/xap0000080. 
Searles, H. F. (1960). The nonhuman environment. Oxford: International University Press.

Silver, H. (2010). Divided cities in the Middle East. City \& Community, 9(4), 345-357. https://doi.org/10.1111/j.1540-6040.2010.01348.x.

Smeekes, A. N., McKeown, S., \& Psaltis, C. (2017). Endorsing narratives under threat: Maintaining perceived collective continuity through the protective power of Ingroup narratives in Northern Ireland and Cyprus. Journal of Social and Political Psychology, 5(2), 282-300. https://doi.org/10.5964/jspp.v5i2.682.

Strojny, P., Kossowska, M., \& Strojny, A. (2016). Search for expectancyinconsistent information reduces uncertainty better: The role of cognitive capacity. Frontiers in Psychology, 7(395). https://doi.org/10. 3389/fpsyg.2016.00395.

Szumowska, E., Kossowska, M., \& Roets, A. (2018). Motivation to comply with task rules and multitasking performance: The role of need for cognitive closure and goal importance. Motivation and Emotion, 42(3), 360-376. https://doi.org/10.1007/s11031-018-9678-2.

Thompson, S. C., \& Kelley, H. H. (1981). Judgments of responsibility for activities in close relationships. Journal of Personality and Social Psychology, 41(3), 469-477. https://doi.org/10.1037/0022-3514.41. 3.469 .

Tuan, Y. F. (1974). Topophilia. Englewood Cliffs: Prentice-Hall.

Tuan, Y. F. (1977). Space and place: The perspective of experience. University of Minnesota Press.

Tversky, A., \& Kahneman, D. (1973). Availability: A heuristic for judging frequency and probability. Cognitive Psychology, 5(2), 207-232. https://doi.org/10.1017/cbo9780511809477.012.

Twigger-Ross, C., \& Uzzell, D. L. (1996). Place and identity processes. Journal of Environmental Psychology, 16, 139-169.

Van Bavel, J. J., \& Pereira, A. (2018). The partisan brain: An identitybased model of political belief. Trends in Cognitive Sciences, 22(3), 213-224. https://doi.org/10.1016/j.tics.2018.01.004.

Verkuyten, M. (2007). Ethnic ingroup favoritism among minority and majority groups: Testing the self-esteem hypothesis among preadolescents. Journal of Applied Social Psychology, 37(3), 486-500. https://doi.org/10.1177/1368430207078695.
Viola, V., Tosoni, A., Brizi, A., Salvato, I., Kruglanski, A. W., Galati, G., \& Mannetti, L. (2015). Need for cognitive closure modulates how perceptual decisions are affected by task difficulty and outcome relevance. PLoS One, 10(12), e0146002. https://doi.org/10.1371/ journal.pone.0146002.

Wallenius, M. (1999). Personal projects in everyday places: Perceived supportiveness of the environment and psychological well-being. Journal of Environmental Psychology, 19(2), 131-143. https://doi. org/10.1006/jevp.1998.0118.

Wang, C. H., \& Kao, Y. T. (2017). Re-assembling the memorial landscape: The politics of walking tours in Taipei. International Journal of Heritage Studies, 23(10), 1002-1016. https://doi.org/10.1080/ 13527258.2017 .1362575$.

Webster, D. M., \& Kruglanski, A. W. (1994). Individual differences in need for cognitive closure. Journal of Personality and Social Psychology, 67(6), 1049-1062. https://doi.org/10.1037/0022-3514. 67.6.1049.

Wnuk, A., Oleksy, T., Toruńczyk-Ruiz, S., Prusik, M., Kula, A., \& Lewicka, M. (2019). Essentialist vs. anti-essentialist place preference: Implications for intergroup attitudes. Manuscript submitted for publication.

Zamora-Musa, R., Vélez, J., \& Paez-Logreira, H. (2018). Evaluating learnability in a 3D heritage tour. Presence: Teleoperators and Virtual Environments, 26(4), 366-377.

Zaromb, F. M., Liu, J. H., Páez, D., Hanke, K., Putnam, A. L., \& Roediger, H. L. (2018). We made history: Citizens of 35 countries overestimate their Nation's role in world history. Journal of Applied Research in Memory and Cognition, 7(4), 521-528. https://doi.org/ 10.1016/j.jarmac.2018.05.006.

Zerubavel, E. (2003). Time maps. Collective memory and the social shape of the past. Chicago: The University of Chicago Press.

Publisher's note Springer Nature remains neutral with regard to jurisdictional claims in published maps and institutional affiliations. 